\title{
Amlodipine induced gingival enlargement
}

\author{
Satya Ranjan Misra, ${ }^{1}$ Sushmita Koduru Lakshmi, ${ }^{1}$ Neeta Mohanty ${ }^{2}$
}

${ }^{1}$ Oral Medicine \& Radiology, Institute of Dental Sciences, Siksha 0 Anusandhan University, Bhubaneswar, Odisha, India

${ }^{2}$ Oral \& Maxillofacial Pathology, Siksha 0 Anusandhan University Institute of Dental Sciences, Bhubaneswar, Odisha, India

\section{Correspondence to} Professor Neeta Mohanty; neetamohanty@soa.ac.in

Accepted 16 July 2021
D Check for updates

(c) BMJ Publishing Group Limited 2021. No commercial re-use. See rights and permissions. Published by BMJ.

\begin{tabular}{|l|}
\hline To cite: Misra SR, \\
Koduru Lakshmi S, \\
Mohanty N. BMJ Case \\
Rep 2021;14:e245098. \\
doi:10.1136/bcr-2021- \\
245098 \\
\hline
\end{tabular}

\section{DESCRIPTION}

Gingival enlargement be it generalised or localised, with its aesthetic implications and potential to provide a niche for multiplication of microbial flora, presents as a diagnostic dilemma to the clinician. ${ }^{1}$ A plethora of causes including heredity, inflammation, drugs or systemic disease can be linked to it (figure 1). Calcium channel blockers like nifedipine and amlodipine are implicated, even though the aetiopathogenesis is poorly understood. ${ }^{2}$

There are both inflammatory and noninflammatory mechanisms involved. The accumulation of the drug in the gingival crevicular fluid in the presence of bacteria can lead to upregulation of proinflammatory cytokines leading to gingival enlargement. ${ }^{3}$ Even decreased folic acid uptake leads to defective collagenase activity, increased adrenocorticotrophic hormone due to feedback from adrenal cortex following blockage of aldosterone synthesis and upregulation of keratinocyte growth factor contribute to the non-inflammatory mechanisms. $^{23}$

The management involves oral prophylaxis, meticulous oral self-care and substitution of the antihypertensive drug which is enough for resolution of the enlargement. For extensive cases, gingivectomy may be performed.

A 67-year-old female patient reported swelling in gums for 1 year. History revealed that both the maxillary and mandibular gingiva gradually and progressively grew in size but were painless and was not associated with bleeding. The patient was hypertensive and was on amlodipine $5 \mathrm{mg}$ and atenolol $50 \mathrm{mg}$ once per day dose. Intraoral examination revealed generalised gingival enlargement involving marginal gingiva, attached gingiva and interdental papilla with extension of enlargement in palatal and lingual aspect of maxillary and mandibular arch respectively, bulbous contour, and lobulated appearance in mandibular anterior teeth

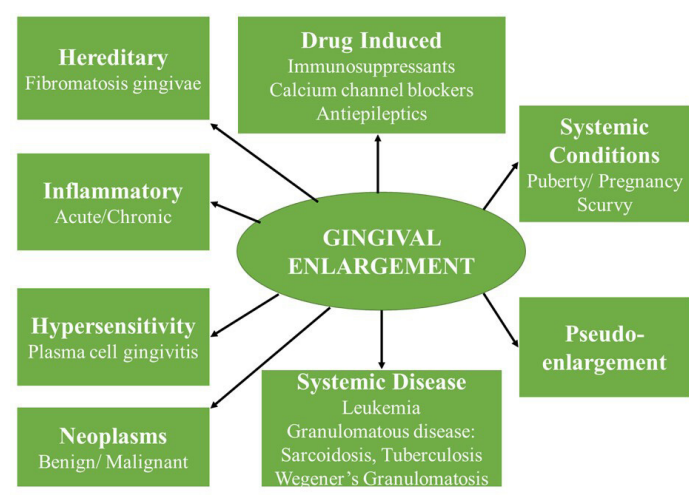

Figure 1 Flow diagram showing various causes of gingival enlargement.

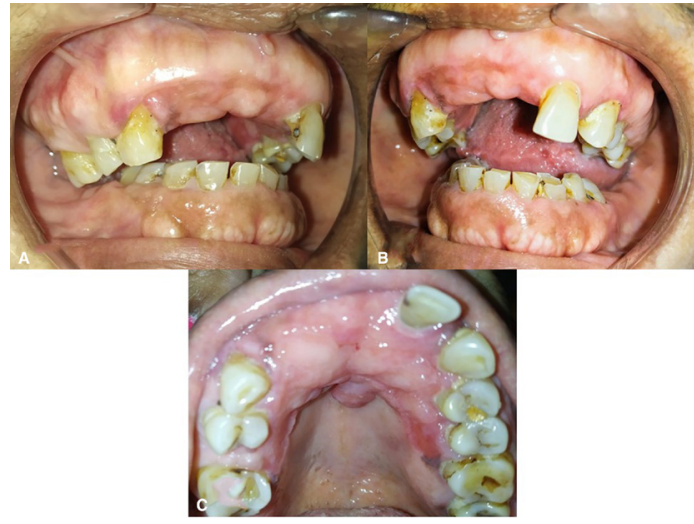

Figure 2 Generalised enlargement of the free, attached and interdental gingiva in the maxilla and mandible $(A, B)$ with a pedunculated, lobulated growth in the midline of the hard palate (C).

region with loss of scalloping (figure 2). On palpation the gingiva was firm, non-tender and leathery in consistency. Palatally, there was a lobulated ovoid out-growth on the mid-palatine raphe region from the enlarged gingiva which was pedunculated, firm and non-tender, interfering with speech and mastication. Maxillary occlusal and panoramic radiographs showed no abnormality. The haemogram was also normal. The pedunculated mass in the midline of the palate extending from the gingiva was excised under local anaesthesia and histologically evaluated, revealing dense fibro-collagenous stroma having chronic inflammatory cell infiltration at places with many small blood vessels, suggestive of fibrous hyperplasia (figure 3). The histopathological diagnosis was clinically correlated to calcium channel blocker amlodipine and a diagnosis of druginduced gingival enlargement was made. Following oral prophylaxis and oral hygiene instructions, the

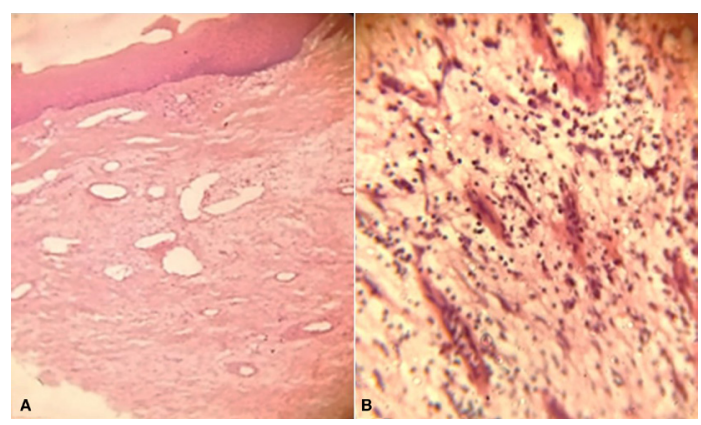

Figure $3 \quad H \& E$ stained microsections showing dense fibro-collagenous stroma having chronic inflammatory cell infiltration at places with many small blood vessels, suggestive of fibrous hyperplasia. (A) Original magnification 10x; (B) original magnification 40x. 


\section{Learning points}

- Gingival enlargement represents abnormal growth of gingival tissues and could be inflammatory, medication-induced, hereditary gingival fibromatosis or due to systemic causes.

- Gingival enlargement could indicate underlying systemic disease and a meticulous history with pertinent investigations are required for diagnosis.

- Drug-induced gingival enlargement requires identification and substitution of the offending drug along with maintenance of proper oral hygiene for resolution.

patient was referred to a physician who substituted amlodipine with losartan potassium. The patient was unwilling for gingivectomy and was lost to follow-up during the pandemic.
Contributors SRM prepared the manuscript. SKL examined the patient and performed the biopsy. NM performed the histopathological evaluation.

Funding The authors have not declared a specific grant for this research from any funding agency in the public, commercial or not-for-profit sectors.

Competing interests None declared.

Patient consent for publication Obtained.

Provenance and peer review Not commissioned; externally peer reviewed.

\section{REFERENCES}

1 Dongari-Baqtzoglou A. Research, science and therapy Committee, American Academy of periodontology. Drug-associated gingival enlargement. J Periodontol 2004; 75:1424-31

2 Grover V, Kapoor A, Marya CM. Amlodipine induced gingival hyperplasia. J Oral Health Comm Dent 2007:1:19-22.

3 Sucu M, Yuce M, Davutoglu V. Amlodipine-induced massive gingival hypertrophy. Can Fam Physician 2011;57:436-7.

Copyright 2021 BMJ Publishing Group. All rights reserved. For permission to reuse any of this content visit

https://www.bmj.com/company/products-services/rights-and-licensing/permissions/

BMJ Case Report Fellows may re-use this article for personal use and teaching without any further permission.

Become a Fellow of BMJ Case Reports today and you can:

- Submit as many cases as you like

- Enjoy fast sympathetic peer review and rapid publication of accepted articles

- Access all the published articles

Re-use any of the published material for personal use and teaching without further permission

Customer Service

If you have any further queries about your subscription, please contact our customer services team on +44 (0) 2071111105 or via email at support@bmj.com.

Visit casereports.bmj.com for more articles like this and to become a Fellow 